\title{
Yaşlılarda kolon divertikülleri: Bir vaka-kontrol çalışması
}

\author{
Colonic diverticulosis in the elderly: A case-kontrol study
}

Abdurrahman ŞAHIN ${ }^{1}$, Nurettin TUNÇ ${ }^{1}$, Bedrettin ORHAN ${ }^{2}$, Mehmet YALNIZ ${ }^{1}$, Salih KILIÇ ${ }^{1}$, Ulvi DEMIREL ${ }^{1}$, Orhan Kürşat POYRAZOĞLU ${ }^{1}$, Ibrahim Halil BAHÇECIOĞLU ${ }^{1}$

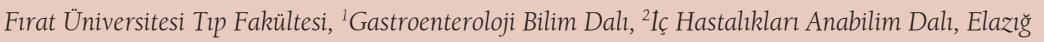

Giriş ve Amaç: Divertikülozis sık görülen bir durumdur. Hastaların çoğunda asemptomatik divertikülozis gözlenirken yaklașık bește birinde semptomatik divertiküler hastalık gelişir. Divertikülozis gelişimi gençlikte nadirken, yaşllıkta görülme sıklığı artar. Altmış beş yaş üstü erişkinlerin yarısından fazlasında divertiküller bulunur. Bu çalışmada, divertikül gelişen yaşlı hastaların klinik ve laboratuvar özelliklerinin belirlenmesi ve divertikülü olmayanlarla karşılaştırılması amaçlanmıştır. Gereç ve Yöntem: Bu retrospektif vaka kontrol çalışması, 2011-2016 yılları arasında kolorektal kanser taraması için kolonoskopi yapılan 65 yaş üzeri bireyleri kapsamaktadır. Kolonoskopi ile divertikülozis saptanan hastalar, divertikülozis saptanmayanlarla karşılaştırılmıştır. Karşılaştırma parametreleri demografik veriler, komorbid hastaliklar ve tam kan sayımı, biyokimya, eritrosit sedimantasyon hızı ve C-reaktif proteinden oluşan laboratuvar parametreleridir. Bulgular: Çalışma divertikülozis saptanan 175 hasta ve divertikülozisi olmayan yaş ile cinsiyet yönünden benzer 175 hasta üzerine yapıld. Ortalama yas divertikülozis

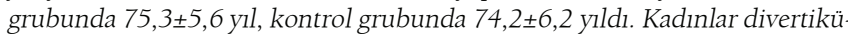
lozis grubunun \%37'sini, kontrol grubunun \%42'sini olușturuyordu. Divertiküller hastaların \%53'ünde sol kolonda, \%9'unda sağ kolonda ve \%38'inde bilateral yerleșimliydi. Gruplar arasında hipertansiyon, diyabetes mellitus ve hiperlipidemi bulunması açısından fark gözlenmedi. Ortanca eritrosit sedimantasyon hızı, divertikülozis grubunda, kontrol grubundan daha yüksekti [21 (2-67) $\mathrm{mm} /$ saate karşı $17(3-59) \mathrm{mm} / \mathrm{saat}, p=0.03]$. C-reaktif protein açısından gruplar arası fark saptanmadı [4 (0,3-75) mg/L'e karşı 3,5 (1,143,5) $\mathrm{mg} / \mathrm{L}, p=0,71]$. Gruplar arasinda farkl tek biyokimyasal parametre kreatinindi. Ortanca kreatinin değeri divertikülozis grubunda $[0,90 \mathrm{mg} / \mathrm{dL}$ $(0,32-2,16)]$, kontrol grubuna göre $[0,82 \mathrm{mg} / \mathrm{dL}(0,37-2,41)]$ daha yüksekti $(p=0,005)$. Sonuç: Önceki çalışmaların aksine, bu çalışmada, kontrollerle karşılaştırıldığında, divertikülozisli hastalarda yüksek hipertansiyon prevalansı saptanmadı. Bulgularımız, geriatrik popülasyonda, divertikülozisli hastalarda gözlenen daha yüksek kreatinin değerlerinin renal bozukluktan ziyade, iyi bilinen bir divertikülozis risk faktörü olan obezite ile ilişkili olabileceğini düşündürmektedir. Erişkin dönemde görülen obezite, ileri yaşlarda, protein-enerji malnütrisyonu ve sarkopeni gelişiminden kısmi olarak koruyucu olabilir. Divertikülozisli yaşh hastalarda gözlenen yüksek eritrosit sedimantasyon hızı değerleri devam eden düşük düzey inflamasyonun indirekt bir göstergesi olabilir

Anahtar kelimeler: Divertikülozis, ileri yaş, hipertansiyon, eritrosit sedimantasyon hızı, C reaktif protein, kreatinin

\section{GİRIS}

Kolon divertikülleri, kas tabakasındaki bazı yetersizlikler nedeniyle mukoza ve submukozanın dışa doğru herniasyonu olarak tanımlanır. Divertikülozis, asemptomatik bireylerde kolonda tek ya da çok sayıda divertikül bulunduğunu be-
Background and Aims: Diverticulosis is a very common condition. While most patients have asymptomatic diverticulosis, around one in five develops symptomatic diverticular disease. The development of diverticulosis is rare in youth, an increase in age being a major risk factor for the development of diverticulosis. Diverticula are found in more than one-half of adults over the age of 65 years. In this study, we aimed to investigate the clinical and laboratory features of geriatric patients who developed diverticulosis and to compare them to subjects with no diverticula. Materials and Methods: This retrospective case-control study included subjects aged over 65 years who underwent a colonoscopy in the period of 2011-2016 for an indication of colorectal cancer screening. Patients with diverticulosis as detected by a colonoscopy were compared to patients without diverticulosis. The comparison parameters included demographic data, comorbidities, and laboratory parameters, including a complete blood count, blood biochemistry, erythrocyte sedimentation rate, and C-reactive protein. Results: The study included 175 patients with diverticulosis whose age and sex matched 175 patients without diverticulosis. The mean age was $75.3 \pm 5.6$ years in the diverticulosis group and $74.2 \pm 6.2$ years in the control group. Females comprised $37 \%$ of the diverticulosis group and $42 \%$ of the control group. Diverticula were predominantly left-sided in 53\%, right-sided in 9\%, and bilateral in 38\%. There was no difference between the groups in terms of the presence of hypertension, diabetes mellitus, and hyperlipidemia. The median erythrocyte sedimentation rate was higher in the diverticulosis group than in the control group (21 mm/hour (2-67) vs $17 \mathrm{~mm} /$ hour (3-59), $p=0.03$ ). We could not detect any difference between the groups in terms of $\mathrm{C}$-reactive protein $[4$ $\mathrm{mg} / \mathrm{L}(0.3-75)$ vs $3.5 \mathrm{mg} / \mathrm{L}$ (1.1-43.5), $p=0.71]$. The only biochemical parameter that was different between the groups was creatinine. The median creatinine was higher $[0.90 \mathrm{mg} / \mathrm{dL}(0.32-2.16)]$ in the diverticulosis group when compared to the control group [0.82 $\mathrm{mg} / \mathrm{dL}(0.37-2.41)](p=0.005)$. Conclusions: Contrary to previous studies, we could not detect a higher prevalence of hypertension in patients with diverticulosis when compared to control subjects in this study. Our findings suggest that higher creatinine values in patients with diverticulosis may not be associated with a renal impairment in the geriatric population; instead, it may be related to obesity, which is a well-known factor for the development of diverticulosis. Obesity in adulthood may relatively contribute to protein-energy malnutrition and sarcopenia in those of an advanced age. A higher erythrocyte sedimentation rate may be an indirect marker of the ongoing low-grade inflammation in geriatric patients with diverticulosis.

Key words: Diverticulosis, advanced age, hypertension, erythrocyte sedimentation rate, C-reactive protein, creatinine

lirten anatomik bir tanımlama olmasına karşın divertiküler hastalık divertiküller ile ilişkili semptomların bulunmasıdır ve hastaların \%20'sinde gözlenir $(1,2)$. Son yllarda, divertiküler hastalıkla ilişkili olarak, semptomatik olan, ancak kolit 
veya divertikülit gibi komplikasyonların gelişmediği hastalar 'semptomatik komplike olmayan divertiküler hastalık' grubu içerisinde tanımlanmaktadır.

Kolon divertikülleri kolonun en sık görülen yapısal hastalığı olup gastrointestinal sistemde (GIS) görülen en sik 5. hastalıktır. Prevalans çalışmaları yaşla birlikte sılılı̆ının arttığını göstermektedir; 40 yaşında olanlarda \%5 oranında gözlenirken, 60 yaşında \%30, 80 yaşında \%50-65 oranında görülmektedir. Diyet, obezite, sigara ve alkol gibi faktörlerle birlikte, ileri yaş en önemli risk faktörlerindendir (1).

Yaşlılarda divertikülozis sıklığının artmış olduğu bilinmesine karşın, divertikül gelişen ve gelişmeyen gruplar arasındaki farklılıklar ile ilgili çalışmalar sınırlıdır. Bu çalışmada 65 yaş üzeri divertikülozis saptanan ve saptanmayan hastaların demografik klinik ve laboratuvar özelliklerinin karşılaştırılması amaçlanmıştır.

\section{GEREC ve YÖNTEM}

Fırat Üniversitesi Tıp Fakültesi Endoskopi ünitesinde, 2011 ile 2016 yılları arasında, çeşitli nedenle kolonoskopi yapılan 65 yaş üzeri hastalar retrospektif olarak değerlendirildi. Hastalar divertikül saptanan ve saptanmayanlar olarak sinıflandırılarak demografik ve klinik özellikleri ile tam kan sayımı, glukoz, alanin aminotransferaz, alkalen fosfataz, üre, kreatinin, total protein, albümin, eritrosit sedimantasyon hızı (ESH) ve C-reaktif protein (CRP) gibi laboratuvar değerleri not edildi. Hastalardan yeterli klinik ve demografik bilgisi bulunmayanlar ile indeks işlemin yapıldığı 3 ay içerisinde laboratuvar değerlendirmesi olmayan veya eksik olanlar çalışma dışı bırakıldı. Bunun yanında malignitesi olanlar, ESH ve/veya CRP değerlerini etkileyebilecek kronik inflamatuvar hastalığı olanlar, son dönem böbrek yetmezliği ve karaciğer sirozu olanlar da çalışma dışı bırakıldı.
Istatistik analizler SPSS 22.00 istatistik programı kullanılarak yapıldı. Sonuçlar kategorik değişkenler için sayı (yüzde), sürekli değişkenler için ortalama \pm standart sapma veya ortanca (minimum-maksimum) şeklinde sunuldu. Grup oranlarının karşılaştırılmasında ki kare ve Fisher's exact test kullanıldı. Grup ortalamalarının karşılaştırılmasında normal dağılım gösteren değişkenler için Student t testi, normal dağılım göstermeyen değişkenler için Mann-Whitney U ile Wilcoxon işaret testleri kullanıldı. $\mathrm{P}<0,05$ istatistik olarak anlamlı kabul edilmiştir.

\section{BULGULAR}

Çalışmaya, 65 yaş üzeri kolonoskopisinde divertikül saptanan 175 hasta ve kolonoskopisinde divertikül saptanmayan 175 hasta alındı. Divertiküller 93 hastada sol kolona sinırlı, 15 hastada sağ kolona sinırlıyken, 67 hastada hem sağ hem de sol kolonda izlendi (Tablo 1). Divertikülü olan hastaların 110'u (\%63) erkek iken, divertikülü olmayan grupta erkeklerin oranı \%58 idi $(\mathrm{p}=0,38)$. Divertikülü olanların ortalama yaşı 75,3 $\pm 5,6$ yıl iken divertikülü olmayanların ortalama yaşı $74,2 \pm 6,2$ yl olarak bulundu ( $\mathrm{p}=0,09)$. Divertikülü olan ve olmayan gruplar arasında diyabetes mellitus (DM), hipertansiyon (HT) ve hiperlipidemi (HL) bulunması açısından anlamlı farklılık saptanmadı (tümü için, p>0,05).

Divertikül olan ve olmayanlar arasında lökosit, hemoglobin ve platelet değerleri açısından istatistik fark saptanmadı (tümü için, p>0,05). Divertikül olan hasta grubunda ortanca ESH değeri $21 \mathrm{~mm} / \mathrm{saatken}$, divertikülü olmayanlarda ortanca ESH değeri $17 \mathrm{~mm} / \mathrm{saat}$ bulundu ( $\mathrm{p}=0.03$ ). Diğer yandan bir akut faz reaktanı olan CRP'nin ortanca değeri, divertikülü olanlarda $4 \mathrm{mg} / \mathrm{L}$, olmayanlarda 3,5 mg/L bulundu $(p=0,71)$. Her iki grup arasında ortanca CRP değeri açısından fark saptanmadi. Hastaların biyokimyasal incelemelerinde ortanca kreatinin değeri, divertikülü olanlarda $0,90 \mathrm{mg} / \mathrm{dL}$

\section{Tablo 1. Divertikülü olan ve olmayan hastaların demografik ve klinik özellikleri}

\begin{tabular}{|c|c|c|c|c|}
\hline & & $\begin{array}{l}\text { Divertikülü Olan Hastalar } \\
\qquad(\mathrm{n}=175)\end{array}$ & $\begin{array}{l}\text { Divertikülü Olmayan Hastalar } \\
\qquad(\mathrm{n}=175)\end{array}$ & $\mathrm{p}$ \\
\hline Yaş & ort \pm ss & $75,3 \pm 5,6$ & $74,2 \pm 6,2$ & 0,09 \\
\hline Cinsiyet & $\begin{array}{l}\text { Erkek } \\
\text { Kadın }\end{array}$ & $\begin{array}{l}110(63) \\
65(37)\end{array}$ & $\begin{array}{l}102(58) \\
73(42)\end{array}$ & 0,38 \\
\hline Diyabetes Mellitus & $(\%)$ & $31(18)$ & $44(25)$ & 0,09 \\
\hline Hipertansiyon & $(\%)$ & $71(40)$ & 68 (39) & 0,74 \\
\hline Hiperlipidemi & (\%) & 39 (22) & $40(23)$ & 0,90 \\
\hline Divertikül lokalizasyonu & $\begin{array}{l}\text { Sol kolon (\%) } \\
\text { Sağ kolon (\%) } \\
\text { Tüm kolon (\%) }\end{array}$ & $\begin{array}{c}93(53) \\
15(9) \\
67(38)\end{array}$ & $\begin{array}{l}- \\
-\end{array}$ & \\
\hline
\end{tabular}


Tablo 2. Divertikülü olan ve olmayan hastaların laboratuvar bulguları

\begin{tabular}{|c|c|c|c|c|}
\hline & & $\begin{array}{l}\text { Divertikülü Olan Hastalar } \\
\qquad(\mathrm{n}=175)\end{array}$ & $\begin{array}{l}\text { Divertikülü Olmayan Hastalar } \\
\qquad(\mathrm{n}=175)\end{array}$ & $\mathrm{p}$ \\
\hline Lökosit & $\left(\mathrm{x} 10^{3} / \mathrm{uL}\right)$ & $7.030(3.700-13.200)$ & $7.160(2.690-12.700)$ & 0,47 \\
\hline Hemoglobin & $(\mathrm{g} / \mathrm{dL})$ & $12,9 \pm 1,8$ & $12,9 \pm 2,2$ & 0,99 \\
\hline Platelet & $\left(\mathrm{x} 10^{3} / \mathrm{uL}\right)$ & $249,5(82-646)$ & $254(76-555)$ & 0,69 \\
\hline Glukoz & (mg/dL) & $100(56-263)$ & $102(64-291)$ & 0,41 \\
\hline ALT & (U/L) & $16(6-55)$ & $17(6-55)$ & 0,48 \\
\hline ALP & (U/L) & $66,5(7-168)$ & $76(15-143)$ & 0,06 \\
\hline Üre & $(\mathrm{mg} / \mathrm{dL})$ & $40,5(16-114)$ & $39(18-99)$ & 0,28 \\
\hline Kreatinin & $(\mathrm{mg} / \mathrm{dL})$ & $0,90(0,32-2,16)$ & $0,82(0,37-2,41)$ & 0,005 \\
\hline Total protein & $(\mathrm{g} / \mathrm{dL})$ & $6,9 \pm 0,7$ & $7,1 \pm 0,6$ & 0,03 \\
\hline Albümin & $(\mathrm{g} / \mathrm{dL})$ & $4,0 \pm 0,5$ & $4,1 \pm 0,4$ & 0,01 \\
\hline ESH & (mm/saat) & $21(2-67)$ & $17(3-59)$ & 0,03 \\
\hline CRP & $(\mathrm{mg} / \mathrm{L})(0-5)$ & $4(0,3-75)$ & $3,5(1,1-43,5)$ & 0,71 \\
\hline
\end{tabular}

ALT; Alanin aminotransferaz, ALP; Alkalen fosfataz, CRP; C-reaktif protein, ESH: Eritrosit sedimantasyon hızı

bulunmuşken, divertikül olmayanlarda $0,82 \mathrm{mg} / \mathrm{dL}$ bulundu $(\mathrm{p}=0,005)$. Üre değerlerinin ortancasının, divertikülü olanlarda ve olmayanlarda farlılık göstermediği görüldü (sırasıyla $40,5 \mathrm{mg} / \mathrm{dL}$ 'ye karşı $39 \mathrm{mg} / \mathrm{dL}, \mathrm{p}=0$,28). Ortalama protein değeri divertikülü olanlarda, divertikülü olmayanlara göre dü-

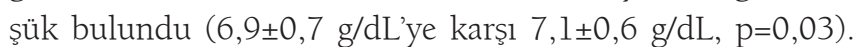
Benzer şekilde, düvertikülü olanlarda ortalama albümin değeri, divertikülü olmayanlara göre düşük saptandı $(4,0 \pm 0,5 \mathrm{~g} /$ dL'ye karşı 4,1 $\pm 0,4 \mathrm{~g} / \mathrm{dL}, \mathrm{p}=0,01)$. Divertikülü olan ve olmayan hasta gruplarının laboratuvar değerleri ve bu değerlerin karşılaşıtırması Tablo 2'de verilmiştir.

\section{TARTISMA}

Hastaların çoğunun asemptomatik olması dolayısıyla divertikülozis prevalansını tam olarak hesaplamak çok kolay olmamasına karşın, divertikülozisin en sık görülen benign kolon patolojisi olduğu ve yaşa bağlı olarak görülme sıklığı arttığı bilinmektedir (3). Divertikülozis ve divertiküler hastalığın etyopatogenezi, bugüne kadar tam aydınlatılamamıştır. Ancak, yapılan epidemiyolojik çalışmalarda, divertikülozis görülme sıklığının arttığı çeşitli faktörler ve hastalıklar tanımlanmıştır. $\mathrm{Bu}$ durumların başında yaşlanma gelmektedir. Birçok epidemiyolojik çalışmada, divertikülozis ve divetiküler hastalık görülme sıklığının yaşla birlikte arttığı ortaya konulmuştur. Yaşlanmaya bağlı birçok fizyolojik değişiklik gerçekleşmektedir. Bunlardan birisi de yağsız vücut kütlesi olarak da isimlendirilen, ekstrasellüler sıvı ve kollajen ve kemik mineralleri gibi ekstrasellüler solid yapılarda azalmadır. Yine yaşlanma ile birlikte ortaya çıkan nörodejenerasyon, peristaltizmin inhibisyonuna ve lümen içi basıncın artmasına yol açarak kolon destek yapılarında gözlenen zayıflıkla birlikte divertikül oluşumuna yol açar (4).

Çalışmamızda, kolon divertiküllerinin \%53'ünün sol kolonda, \%15'inin sağ kolonda, \%32'sinin ise bilateral yerleşimli olduğu görüldü. Kolon divertiküllerinin dağılımı coğrafik olarak farklılık göstermektedir. Batı toplumları ve Afrika'da daha çok sol kolonda divertikül görülürken, Asya toplumlarında sağ kolon yerleşimli divertiküllere daha sık rastlanır. Yakın zamanda yayınlanan bir Orta Doğu çalışmasında, kolon divertikülü olan hastaların \%61'inin erkek olduğu ve kolon divertiküllerinin \%62'sinin sol kolonda, \%13’ünün sağ kolonda, \%25'inin ise bilateral yerleşimli olduğu görülmüştür (5). Bulgularımız, yukarıdaki bulgular ile birlikte değerlendirildiğinde, kolon divertiküllerinin dağılımının Batı ülkeleri ve Afrika ülkeleri ile benzer olduğu gözlenmiştir.

Olgular, kronik hastalıklar açısından incelendiğinde, divertikülozisli olgularla yaş ve cinsiyet yönünden benzer kontrol grubu arasında fark gözlenmemiştir. Her iki grupta da en sık gözlenen kronik hastalık yaklaşı \%40 oranında hipertansiyondur. Literatürde divertikülozis ile kronik hastalıklar arasındaki ilişki yönünden çelişkili sonuçlar bulunmaktadır. Japonya'dan 51-59 yaşları arasında hastaları kapsayan bir çalışmada divertikülozisli hastalarda, divertikül saptanmayanlara göre, kronik hastalıklar açısından sadece diyabet ve hipertansiyonun daha sık gözlendiği bulunmuştur (6). Bahsedilen çalışmada, divertikülü olan ve olmayan hastalar arasinda, HT sirasiyla \%31 ve \%20, DM ise sirasiyla \%21,5 ve \%14 bulunmuştur. Benzer sonuçlar Ortadoğu çalışmasında da gözlenmiş olup HT, DM ve HL divertikülozisli hastalarda 
daha yüksek oranda saptanmıştır (5). Divertikül olanlarda HT \%64 gibi yüksek bir oranda saptanmasının yanında, HT mevcudiyetinin divertikülozis görülme olasılığını 2,3 kat artırdığı bulunmuştur. Bu sonuçların aksine, İsrail'den yapılan bir çalışmada, DM ve hipotiroidinin divertikülozis ile ilişkili olduğu, HT ve HL bulunmasının ise divertikülozis ile ilişkili olmadığını gösterilmişsir. Çalışmamızda, yaş ve cinsiyet yönünden benzer gruplar arası yapılan karşılaştırmada, DM, HT ve HL bulunması yönünden fark saptanmadı. Literatürde mevcut çalışmaların çoğu, retrospektif ve randomize kontrollü olmayan çalışmalar olup farklı hasta gruplarının değerlendirildiği çalışmalardır. Bu nedenle divertikülozis ile kronik hastalık ilişkisi ile ilgili genellemelerin çıkarılması olası görülmemektedir. Bu konuda, geniş ölçekli, prospektif, randomize kontrollü çalışmalara gereksinim vardır. Her ne kadar, HT ve DM hastalıklarına eşlik edecek aterosklerotik süreç ve diyabetik hastalarda ortaya çıkabilen dismotilite divertikül gelişiminde suçlansa da, mevcut bulgular DM ve HT'un divertikülozis gelişimine katkılarını tam olarak ortaya koyamamaktadır. Divertikülozis gelişiminin daha iyi anlaşılması için hastalık etyopatogenezini etkileyen faktörlerin belirlenmesi açısından yeni çalışmalar gereklidir.

Inflamatuvar belirteçler açısından değerlendirildiğinde, CRP değerlerinin iki grupta da benzer olmasına karşın ESH değerleri divertiküllü hastalarda daha yüksek bulunmuştur. Divertiküllü bir hastada, kusma olmadan sol alt kadran hassasiyeti ile birlikte CRP değerinin $50 \mathrm{mg} / \mathrm{dL}$ 'nin üzerinde olması akut divertikülit atağı tanısında oldukça değerlidir (8). Bir başka çalışmada, akut divertikülit atağının belirlenmesinde bağımsız faktörler olarak; sol alt kadranda lokalize hassasiyet, 50 yaş üzeri olmak, kusmanın olmaması ve CRP değerinin $50 \mathrm{mg} / \mathrm{L}$ üzerinde olması bulunmuştur (9). Bu çalışmalar CRP'nin akut divertikülit gibi akut inflamasyon durumlarının tahmininde kullanılabilecek bir belirteç olduğunu göstermektedir. Çalışma grubumuzun asemptomatik divertikülozisli hastalardan oluşması ve bu hastalarda akut inflamasyon görülmemesi, CRP değerlerinin, inflamatuvar hastalıkları olmayan kontrollerle farklı olmamasını açıklıyor olabilir. Yine, akut inflamasyonun bir diğer göstergesi olan lökositozun divertikülozisli hastalarda gözlenmemesi ve lökosit sayısının kontrollerle benzer olması her iki grupta da akut inflamatuvar bir süreç gerçekleşmediğini göstermesi açısından destekleyici bir bulgudur. Bunun yanında, iki grup arasında CRP değerleri yönünden fark gözlenmezken ESH değerlerinin divertikülozisli hastalarda yüksek olması, devam eden düşük düzeyde sistemik inflamasyonla ilişkili olabilir. C-reaktif protein, direkt bir akut faz reaktanı olup düzeyleri kısa dönemlerde inflamasyonla ilişkili olarak değişiklik gösterirken, inflamasyonun indirekt bir göstergesi olan ESH'nın değişimi daha uzun sürelidir. Özellikle, semptomatik komplike olmayan divertiküler hastalık gruplarında, mikrobiyata değişiklikleri ve devam eden kronik düşük düzeyde inflamasyonla ilişkili çok sayıda kanıt ortaya konulmuştur (2). Semptomatik komplike olmayan divertiküler hastalıkta ortaya çıkan patolojik immün yanıt ve düşük dereceli sistemik inflamasyonun semptomların ortaya çıkışına yol açtığı gösterilmiştir (10). Divertiküllü hastalarda gözlenen düşük düzeyli kronik sistemik inflamasyon, -yaşllar için normal kabul edilen sinırlar içerisine olsa da- bu hasta grubundaki ESH yüksekliğini açıklayabilir. Bu çalışmanın retrospektif olması nedeniyle hastalar semptomları yönünden sorgulanamamıştır. Çalışmamızın kısıtllılılarindan olan bu durum nedeniyle hasta grubumuzda, semptomatik komplike olmayan divertiküler hastalığı olanların oranların bilemediğimiz için, divertiküllü hasta grubunda gözlenen ESH yüksekliğinin yukarıda açıklanan semptomatik komplike olmayan divertiküler hastalıkla açıklanması güçtür. Bu konuda prospektif, çok sayıda hastanın katıldığı çalışmalara gereksinim vardır.

Bu çalışmanın, ilginç bir bulgusu da divertiküllü hastaların kreatinin değerlerinin kontrol grubundan yüksek olmasıdır. Yapılan çalışmalarda, kronik böbrek yetmezliği, özellikle de otozomal dominant polikistik böbrek hastalığı olanlarda divertikül sıklığının genel topluma göre artmadığı gözlenmiştir $(3,11)$. Mevcut bulgular, böbrek fonksiyonlarında ortaya çıan bozukluktan ziyade, serum kreatinin düzeyinin vücut kas kitlesinin dolaylı bir göstergeci olması ile açıklanabilir. Yaşlllarda sarkopeni iyi bilinen fizyolojik bir özelliktir. Yaşlılar malnütrisyona daha yatkın olmakla birlikte obezite ve dengesiz beslenme de bu yaş grubu hastalarda gözlenebilmektedir. Obezite, divertikülozis gelişimi açısından iyi bilinen bir risk faktörüdür (4). Divertikülü olan hastalarda obezite öyküsünün bulunması, kas yıkımına neden olan protein enerji malnütrisyonun gelişimine diğer bireylerden daha dirençli olduklarını düşündürmektedir. Yaşlılarda malnütrisyon ve sarkopeniye bağlı kas yıkımı sonucu ölçülen kreatinin değerleri beklenen düzeylerden düşük olabilir. Bu durum, yaşla uyumlu olarak ortaya çıkan renal fonksiyon kaybının, divertiküllü hastalarda daha doğru bir biçimde yapılabildiğini, divertikül olmayan yaşlı bireylerde ise malnütrisyon ve sarkopeniye bağlı olarak serum kreatinin düzeylerinin yalanc1-düşük olabileceğini akla getirmektedir.

Sonuç olarak divertikül görülmesi yaşla birlikte artar ve en çok yaşlı popülasyonda gözlenir. Yaşlllığa bağlı oluşan fizyolojik değişiklikler, bu hasta grubunda değerlendirmeyi karmaşı hale getirmektedir. Çalışma grubumuzda divertiküllü hastalarda serum kreatinin değerinin yüksek olması, divertikül oluşumunda önemli bir faktör olan obeziteye bağlı olarak, yaşlı hastalarda protein enerji malnütrisyonu ve sarkopeniden göreceli olarak korunduğunu düşündürmektedir. Günümüzde kronik inflamatuvar bir hastalık olarak kabul edilen divertikülozis, yol açtığı düşük düzey kronik inflamasyona bağlı ESH değerlerinde artışa neden olmaktadır. Yüksek ESH değerlerine CRP yüksekliğini eşlik etmemesi, CRP'nin tanıda yarımcı olmaktan ziyade, akut divertikülit gibi komplikasyonların varlığında değerli bir belirteç olarak kullanılabileceğini göstermektedir. 


\section{KAYNAKLAR}

1. Strate LL. Lifestyle factors and the course of diverticular disease. Dig Dis 2012;30:35-45.

2. Tursi A, Papa A, Danese S. Review article: the pathophysiology and medical management of diverticulosis and diverticular disease of the colon. Aliment Pharmacol Ther 2015;42:664-84.

3. Böhm, SK. Risk factors for diverticulosis, diverticulitis, diverticular perforation, and bleeding: A plea for more subtle history taking. Viszeralmedizin 2015;31:84-94.

4. Spiller RC. Changing views on diverticular disease: impact of aging, obesity, diet, and microbiota. Neurogastroenterol Motil 2015;27:305-12.

5. Azzam N, Aljebreen AM, Alharbi O, Almadi MA. Prevalence and clinical features of colonic diverticulosis in a Middle Eastern population. World J Gastrointest Endosc 2013;5:391-7.

6. Sakuta H, Suzuki T. Prevalence Rates of type 2 diabetes and hypertension are elevated among middle-aged Japanese men with colonic diverticulum. Environ Health Prev Med 2007;12:97-100.
7. Kopylov U, Ben-Horin S, Lahat A, et al. Obesity, metabolic syndrome and the risk of development of colonic diverticulosis. Digestion 2012;86:201-5.

8. Lameris W, van Randen A, van Gulik TM, et al. A clinical decision rule to establish the diagnosis of acute diverticulitis at the emergency department. Dis Colon Rectum 2010;53:896-904.

9. Andeweg CS, Knobben L, Hendriks JC, et al. How to diagnose acute left-sided colonic diverticulitis: proposal for a clinical scoring system. Ann Surg 2011;253:940-6.

10. Scaioli E, Colecchia A, Marasco G, et al. Pathophysiology and therapeutic strategies for symptomatic uncomplicated diverticular disease of the colon. Dig Dis Sci 2016;61:673-83.

11. Luciano RL, Dahl NK. Extra-renal manifestations of autosomal dominant polycystic kidney disease (ADPKD): considerations for routine screening and management. Nephrol Dial Transplant 2014;29:247-54. 